\title{
APPROACH TO FERROMAGNETIC SATURATION FOR AMORPHOUS FE-BASED ALLOY
}

The paper presents the results of research on the structure and selected properties of magnetic alloys based on Fe. The alloy with the chemical composition $\mathrm{Fe}_{36} \mathrm{Co}_{36} Y_{8} B_{20}$ was produced using two methods: forcing and sucking the liquid alloy into a copper mould. The alloy was cast in the form of $10 \mathrm{~mm} \times 5 \mathrm{~mm} \times 0.5 \mathrm{~mm}$ tiles. The structure of the obtained alloys was examined using $X$-ray diffraction. The measured diffractograms are typical for amorphous materials. Using the Faraday magnetic balance, the magnetic saturation polarisation curves as a function of temperature were recorded. The Curie temperature of the created alloys, which amounted to approximately $750 \mathrm{~K}$, was determined on the basis of numerical analysis. The original magnetisation curves and static magnetic hysteresis loops were measured using a vibration magnetometer. The produced alloys had a saturation magnetisation of about 1.1T and a coercive field value of about $200 \mathrm{~A} / \mathrm{m}$. The curves of primary magnetisation were analysed using $\mathrm{H}$. Kronmüller's theory. It was found that the magnetising process in the area called the 'approach to ferromagnetic saturation' is related to the rotation of the magnetisation vector around the linear defects of the structure.

Keywords: massive amorphous materials, approach to ferromagnetic saturation, Curie temperature, X-ray diffraction, Holstein-Primakoff paraprocess

\section{PODEJŚCIE DO FERROMAGNETYCZNEGO NASYCENIA DLA AMORFICZNEGO STOPU NA BAZIE ŻELAZA}

W pracy zamieszczono wyniki badań struktury i wybranych właściwości magnetycznych stopów na bazie Fe. Stop o sktadzie chemicznym $\mathrm{Fe}_{36} \mathrm{Co}_{36} Y_{8} B_{20}$ wytworzono dwiema metodami: wttaczania oraz zasysania ciektego stopu do miedzianej formy. Stop odlewano w postaci ptytek o wymiarach $10 \mathrm{~mm} \times 5 \mathrm{~mm} \times 0,5 \mathrm{~mm}$. Strukture otrzymanych stopów badano przy użyciu dyfrakcji rentgenowskiej. Zmierzone dyfraktogramy sa typowe jak dla materiałów amorficznych. Przy użyciu wagi magnetycznej Faraday'a zarejestrowano krzywe magnetycznej polaryzacji nasycenia $w$ funkcji temperatury. Na podstawie analizy numerycznej krzywych wyznaczono temperaturę Curie wytworzonych stopów, która wyniosta około $750 \mathrm{~K}$. Przy użyciu magnetometru wibracyjnego zmierzono pierwotne krzywe magnesowania oraz statyczne pętle histerezy magnetycznej. Wytworzone stopy posiadały magnetyzację nasycenia około 1,1T oraz wartość pola koercji około $200 \mathrm{~A} / \mathrm{m}$. Wykorzystujac teorie H. Kronmüllera, przeprowadzono analize krzywych pierwotnego magnesowania. Stwierdzono, że proces magnesowania w obszarze zwanym podejściem do ferromagnetycznego nasycenia zwiąany jest $z$ obrotem wektora magnetyzacji wokót liniowych defektów struktury.

Stowa kluczowe: masywne materiały amorficzne, podejście do ferromagnetycznego nasycenia, temperatura Curie, dyfrakcja rentgenowska, paraproces Holsteina-Primakoffa

\section{INTRODUCTION}

Amorphous materials have been known for several decades, but they are still an interesting object of research due to their unique properties. The first amorphous materials were produced in the form of thin strips and layers with a thickness of less than $100 \mu \mathrm{m}$ $[1,2]$. The dimensions of these materials significantly limited their applicability. The increased interest in this group of materials resulted in the development of the so-called 'massive amorphous materials' [3, 4]. Massive amorphous alloys are produced at a relatively low cooling rate of $10^{-1}$ to $10^{3} \mathrm{~K} / \mathrm{s}$. Iron alloys are an interesting group of massive amorphous materials. They exhibit the so-called 'magnetically soft properties' [5-9]. Such materials should have a coercive field of less than $1000 \mathrm{~A} / \mathrm{m}$ [10] and high saturation magnetisation [11].

An important feature of ferromagnetic amorphous materials is their Curie temperature. The temperature at which the material passes from the ferromagnetic to the paramagnetic state determines the scope of application of these materials. In order to raise Curie temperature, Fe-based amorphous alloys are used for cobalt [12].

The different properties of amorphous materials with respect to their crystalline counterparts are directly related to their unusual structure typical of liquids. Amorphous structure is characterised by the chaotic arrangement of atoms in the volume of material. Depending on the amount of stress generated when the liquid material solidifies, amorphous alloys can mag- 
netise more easily than their crystalline counterparts. In the case of a large amount of stress, it is possible to improve the magnetic properties of these materials by heating at a temperature below the crystallisation temperature, which leads to the relaxation of the amorphous structure.

The magnetisation process of these alloys is not always the same for samples with identical chemical composition [13]. The differences in the magnetising process are related to the defects of the amorphous structure. They occur in the form of free volumes and pseudo-dislocation dipoles $[14,15]$. Volume equal to or greater than the smallest alloy constituent is considered to be the free volume, while the pseudo-location dipoles are the clusters of free volumes. An evaluation of the type and amount of defects is possible by indirectly studying an area called the 'approach to ferromagnetic saturation'. According to the theory of H. Kronmüller [16], magnetisation near this area can be described with the dependence:

$$
\begin{gathered}
\mu_{0} M(H)=\mu_{0} M_{s}\left[1-\frac{a_{1 / 2}}{\left(\mu_{0} H\right)^{1 / 2}}-\frac{a_{1}}{\left(\mu_{0} H\right)^{1}}-\frac{a_{2}}{\left(\mu_{0} H\right)^{2}}\right]+ \\
+b\left(\mu_{0} H\right)^{1 / 2}
\end{gathered}
$$

where:

$M_{s}$ - spontaneous magnetisation

$\mu_{0}$ - magnetic vacuum permeability

$H$-intensity of magnetic field

$a_{i}$ - angular linear adjustment, which corresponds to free volume and linear defects $(i=1 / 2,1,2)$

$b$-slope of linear fit corresponding to a thermally induced suppression of spin waves by a high intensity magnetic field.

This dependence ignores the influence of internal fluctuations, such as density anisotropy, which is an acceptable simplification due to its insignificant influence on the magnetisation process [17].

The factors in Equation 1 can be described as follows:

$$
\begin{aligned}
& \frac{a_{1 / 2}}{\left(\mu_{0} H\right)^{1 / 2}}=\mu_{0} \frac{3}{20 A_{e x}}\left(\frac{1+r}{1-r}\right)^{2} G^{2} \lambda_{s}^{2}(\Delta V)^{2} N \times \\
& \times\left(\frac{2 A_{e x}}{\mu_{0} M_{s}}\right)^{1 / 2} \frac{1}{\left(\mu_{0} H\right)^{1 / 2}} \\
& \frac{a_{1}}{\mu_{0} H}=1.1 \mu_{0} \frac{G^{2} \lambda_{s}^{2}}{(1-\nu)^{2}} \frac{N b_{e f f}}{M_{s} A_{e x}} D_{d i p}^{2} \frac{1}{\left(\mu_{0} H\right)} \\
& \frac{a_{2}}{\mu_{0} H^{2}}=0.456 \mu_{0} \frac{G^{2} \lambda_{s}^{2}}{(1-\nu)^{2}} \frac{N b_{e f f}}{M_{s}^{2}} D_{d i p}^{2} \frac{1}{\left(\mu_{0} H\right)^{2}}
\end{aligned}
$$

where:

$\Delta V$ - volume change caused by the occurrence of a point defect characterised by density $N$ exchange constant $A_{e x}$

$G$-transverse elastic shear modulus

$r$ - Poisson coefficients

$\lambda_{s}$ - magnetostriction constant.

Equation (2) describes the effect of point defects on the magnetisation process. Dependencies (3) and (4) relate to the influence of pseudo-shift dipoles on this process. Equation (3) describes these defects for the assumption of $D_{d i p}<1 H$, whereas relationship (4) relates to $D_{\text {dip }}>1 H$ where $1 H$ is the distance of at least two dipoles. Further magnetisation process is associated with the suppression of thermally excited spin waves. The $D_{\text {spf }}$ parameter describing the stiffness of this wave can be determined from the dependence:

$$
b=3.54 g \mu_{0} \mu_{B}\left(\frac{1}{4 \pi D_{s p f}}\right)^{3 / 2} k T\left(g \mu_{B}\right)^{1 / 2}
$$

where:

$$
\begin{aligned}
k & \text { - Boltzman's constant } \\
\mu B & \text { - Bohr magneton } \\
g & \text { - gyromagnetic coefficient. }
\end{aligned}
$$

The purpose of the study was to produce volumetric iron-based alloys with the $\mathrm{Fe}_{36} \mathrm{Co}_{36} \mathrm{Y}_{8} \mathrm{~B}_{20}$ chemical composition using the method of pressing and sucking the liquid alloy into a copper mould, examining their structure and selected magnetic properties of the produced materials.

\section{METHODS}

The material in the form of a polycrystalline ingot was made using an arc furnace. The elements used to make the alloy sample were characterised by purity above $99.99 \%$. Samples weighing 5 grams were weighed with an accuracy of 0.001 gram. The ingot was melted with a plasma arc in a protective atmosphere of argon. To ensure the high quality of the ingot, the protective atmosphere was applied during its production. For this purpose, the working chamber of the arc furnace was pumped out using a pump and valve system, and rinsed with argon, whereupon a high vacuum was again created. The melting process was carried out with constant argon pressure in the working chamber. The melting of the ingot was preceded by the melting of the titanium getter, which additionally affects the cleanliness of the working chamber. In order to homogenise the structure, the ingot was melted seven times; each time, it was turned over to the other side using a manipulator.

A method of injecting a liquid alloy into a copper mould was used to produce a massive amorphous alloy. Pieces of a polycrystalline ingot were placed in a quartz capillary with a $1 \mathrm{~mm}$ diameter opening. After the vacuum was created in the working chamber of the device, it was flushed with argon. In addition, the quartz capillary was rinsed to get rid of residual oxygen. The presence of oxygen and other impurities in the working chamber during the melting of the charge has a negative impact on the possibility of formation of amorphous structure during the process of cooling the liquid alloy. The presence of oxygen is particularly negative. The resulting oxides in the volume of polycrystalline ingot become nucleating seeds during the cooling of the liquid alloy. The alloy casting process is carried out in a protective atmosphere of argon. The constant pressure of the protective gas and the pressure constants for the injection of the liquid alloy were used. Cylindrical copper forms were used to cast the alloy in the form of $10 \mathrm{~mm} \times 5 \mathrm{~mm} \times 0.5 \mathrm{~mm}$ tiles. The rate of cooling of the liquid alloy during the production of amorphous materials using this method is up to $10^{3} \mathrm{~K} / \mathrm{s}$.

The rapidly cooled alloy was also produced using the method of aspirating a liquid alloy into a copper mould. This method is quite similar to the injection method. During the production process, identical production parameters were used, such as the level of vacuum 
generated, pressure of argon in the working chamber, type of mould and cooling rate. In the case of the suction method, the batch is melted using a plasma arc, and pure titanium is melted just before the fabrication process. The most important difference is the way in which the liquid alloy is placed in the copper mould.

The structure of the prepared alloy samples was examined using an X-ray diffractometer. A BRUCKER $\mathrm{X}$-ray apparatus equipped with a CuK $\alpha$ lamp was used for this purpose. The test was carried out with a measuring step of $0.02^{\circ}$ with an exposure time of 7 seconds.

The magnetic saturation polarisation curves as a function of temperature were examined using Faraday's magnetic weight. The measurement was carried out in the range from room temperature to $850 \mathrm{~K}$. The Curie temperature of the prepared alloy samples was determined based on numerical analysis of the recorded curves.

The magnetisation measurement as a function of the external magnetic field was taken using a vibration magnetometer in the field of field induction from 0 to $2 T$. The curves of the primary magnetisation in the area of magnetic saturation approach were analysed in accordance with the theory of $\mathrm{H}$. Kronmüller. The spin wave stiffness parameter $D_{s p f}$ was determined by analysing the curves in the area of occurrence of the Holstein-Primakoff process pair.

\section{RESULTS AND DISCUSSION}

Figure 1 presents x-ray diffractograms measured for samples of the produced alloy.

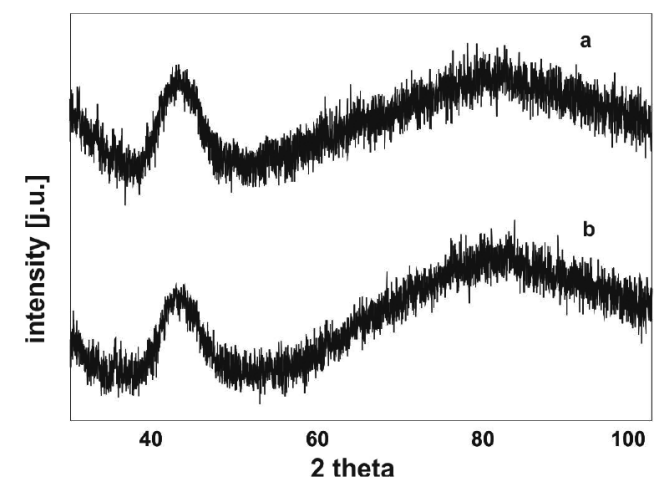

Fig. 1. X-ray diffractograms measured for the $\mathrm{Fe}_{36} \mathrm{Co}_{36} \mathrm{Y}_{8} \mathrm{~B}_{20}$ alloy produced using: a) injection, b) suction

Rys. 1. Dyfraktogramy rentgenowskie mierzone dla stopu $\mathrm{F}_{36} \mathrm{Co}_{36} \mathrm{Y}_{8} \mathrm{~B}_{20}$ wytworzonego metodą: a) wtłaczania, b) zasysania

Diffractograms are typical for amorphous materials. The visible wide maximum in the angle range two theta $40-50^{\circ}$ corresponds to the dispersion of $\mathrm{X}$-rays on randomly arranged atoms in the volume of the test sample. The lack of narrow intense peaks indicates the absence of ordered phases in the volume of the tested samples.

Figure 2 presents reduced magnetic saturation polarisation curves as a function of temperature. The magnetisation measurement as a function of temperature was carried out to a temperature of $850 \mathrm{~K}$ when heating a $10 \mathrm{~K}$ sample per minute. On the recorded curves, there is one inflection from the phase transition from ferromagnetic to paramagnetic. This transition comes from the amorphous phase. It is worth noting that the magnetic saturation polarisation almost decreases to 0 during the measurement. This means that in the volume of the tested samples, there are no other magnetic phases other than the identified amorphous matrix.

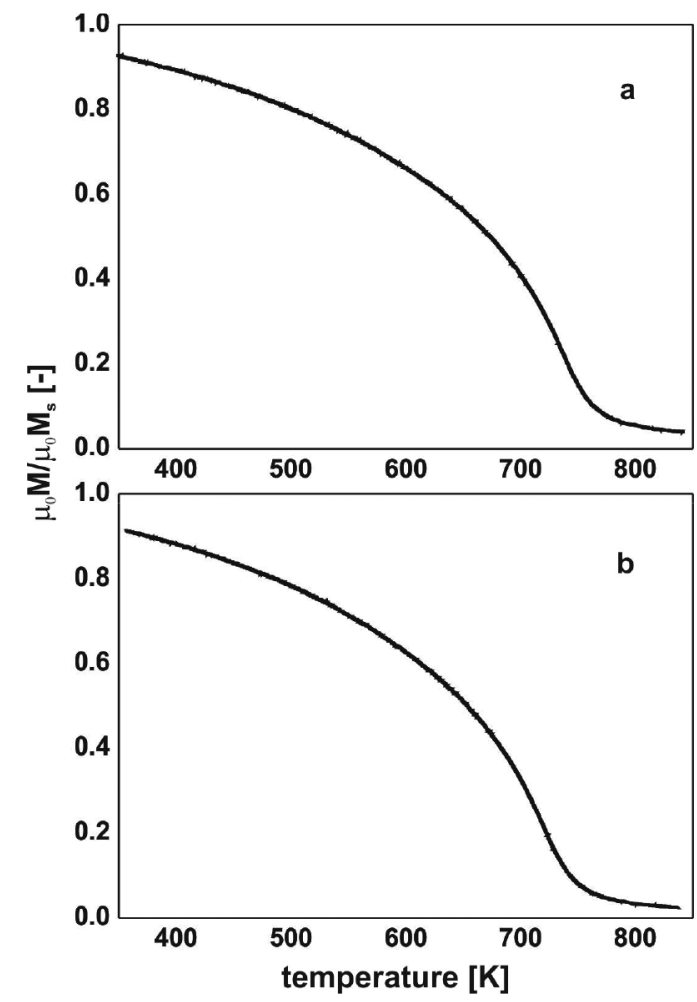

Fig .2. Magnetic saturation polarisation as a function of temperature for the $\mathrm{Fe}_{36} \mathrm{Co}_{36} \mathrm{Y}_{8} \mathrm{~B}_{20}$ alloy produced using: a) injection, b) suction

Rys. 2. Magnetyczna polaryzacja nasycenia w funkcji temperatury dla stopu $\mathrm{Fe}_{36} \mathrm{Co}_{36} \mathrm{Y}_{8} \mathrm{~B}_{20}$ wytworzonego metodą: a) wtlaczania, b) zasysania

Figure 3 presents the results of numerical analysis of the magnetic saturation polarisation curves after the use of the critical coefficient $\beta=0.36$ for ferromagnetic, which meet the Heisenberg assumptions. The Curie temperature determined for the $\mathrm{Fe}_{36} \mathrm{Co}_{36} \mathrm{Y}_{8} \mathrm{~B}_{20}$ alloy produced using the injection method is $745 \mathrm{~K}$. In the case of the alloy cast by suction, the Curie temperature is $750 \mathrm{~K}$.

Figure 4 presents the curves of primary magnetisation for the samples of the produced alloys. The area called the 'approach to ferromagnetic saturation' was predetermined. The analysis of the curves of the primary magnetisation shows that the $\mathrm{Fe}_{36} \mathrm{Co}_{36} \mathrm{Y}_{8} \mathrm{~B}_{20}$ alloy produced using the injection method is magnetised more easily. For the same value of magnetic field induction, the alloy produced using the injection method achieves higher magnetisation than the alloy cast using the suction method. Figure 5 presents the static magnetic hysteresis loops measured for the samples of the tested alloys.

The static hysteresis loops obtained for the tested alloys are typical for materials exhibiting soft magnetic properties. The alloy produced using the injection method is characterised by the saturation magnetisation value of 


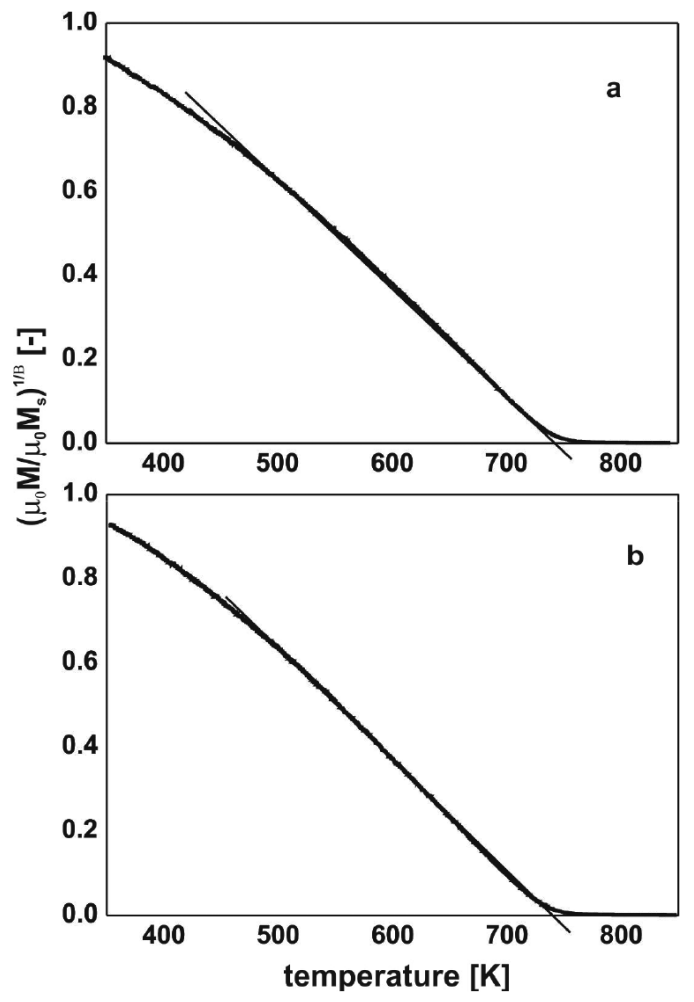

Fig. 3. Curie temperature for the $\mathrm{Fe}_{36} \mathrm{Co}_{36} \mathrm{Y}_{8} \mathrm{~B}_{20}$ alloy produced using: a) injection, b) suction

Rys. 3. Temperatura Curie dla stopu $\mathrm{Fe}_{36} \mathrm{Co}_{36} \mathrm{Y}_{8} \mathrm{~B}_{20}$ wytworzonego metodą: a) wtlaczania, b) zasysania

$1.09 T$ and the value of the restraining area of $208 \mathrm{~A} / \mathrm{m}$. The alloy produced using the suction method showed values of coercive field of up to $212 \mathrm{~A} / \mathrm{m}$. The saturation magnetisation for the tested sample was $1.1 T$. It can be concluded that the method of placing the alloy in the copper form does not affect the saturation magnetisation and the coercive field. The analysis of primary magnetisation curves in accordance with the theory of $\mathrm{H}$. Kronmüller allows indirect identification of defects of the amorphous structure. This analysis is included in Figures 6-8. A linear fit to function $\mu_{0} M\left(\mu_{0} H\right)^{-1}$ and $\mu_{0} M\left(\mu_{0} H\right)^{-2}$ indicates the presence of these structural defects.

Figure 6 shows the dependence of magnetisation as a function $\left(\mu_{0} H\right)^{-1}$ and $\left(\mu_{0} H\right)^{-2}$ for $\mathrm{Fe}_{36} \mathrm{Co}_{36} \mathrm{Y}_{8} \mathrm{~B}_{20}$ made using injection casting.

In the magnetic field from $0.068 T$ to $0.13 T$, the process of sample magnetisation is related to the presence of linear defects in the form of pseudo-location dipoles, for which dependence (3) is satisfied. In a magnetic field with an intensity of $0.14 T$ to $0.48 T$, material magnetisation depends on linear defects apart from each other by a distance exceeding the distance of exchange (dependence (4)).

Figure 7 shows the curve of magnetisation as a function $\left(\mu_{0} H\right)^{-2}$ for a sample of the alloy produced using suction. In this case, the magnetising process is related to the rotation of the magnetisation vector around the pseudo-dislocation dipoles that satisfy dependence (4).

Figure 8 shows the curves of primary magnetisation as a function $\left(\mu_{0} H\right)^{1 / 2}$. Above the area called the 'approach to ferromagnetic saturation', the dominant effect on the magnetising process is the attenuation of thermally excited spin waves. For both alloy samples, this area begins above the magnetic field induction of $0.49 T$.

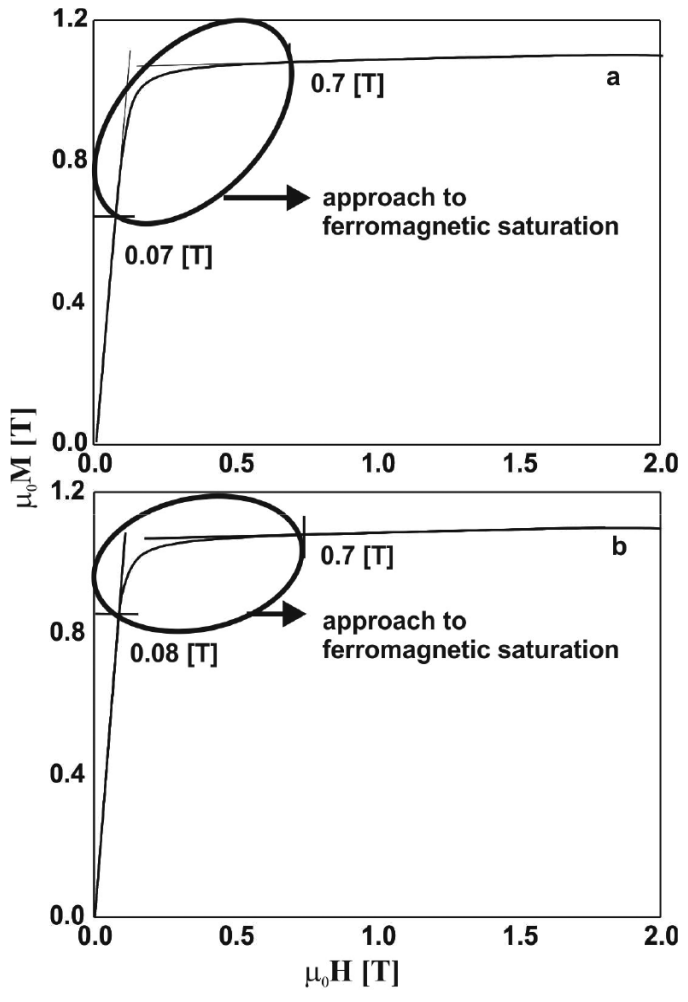

Fig. 4. Primary magnetisation curves for the $\mathrm{Fe}_{36} \mathrm{Co}_{36} \mathrm{Y}_{8} \mathrm{~B}_{20}$ alloy produced using: a) injection, b) suction

Rys. 4. Krzywe pierwotnego magnesowania dla stopu $\mathrm{Fe}_{36} \mathrm{Co}_{36} \mathrm{Y}_{8} \mathrm{~B}_{20}$ wytworzonego metodą: a) wtłaczania, b) zasysania

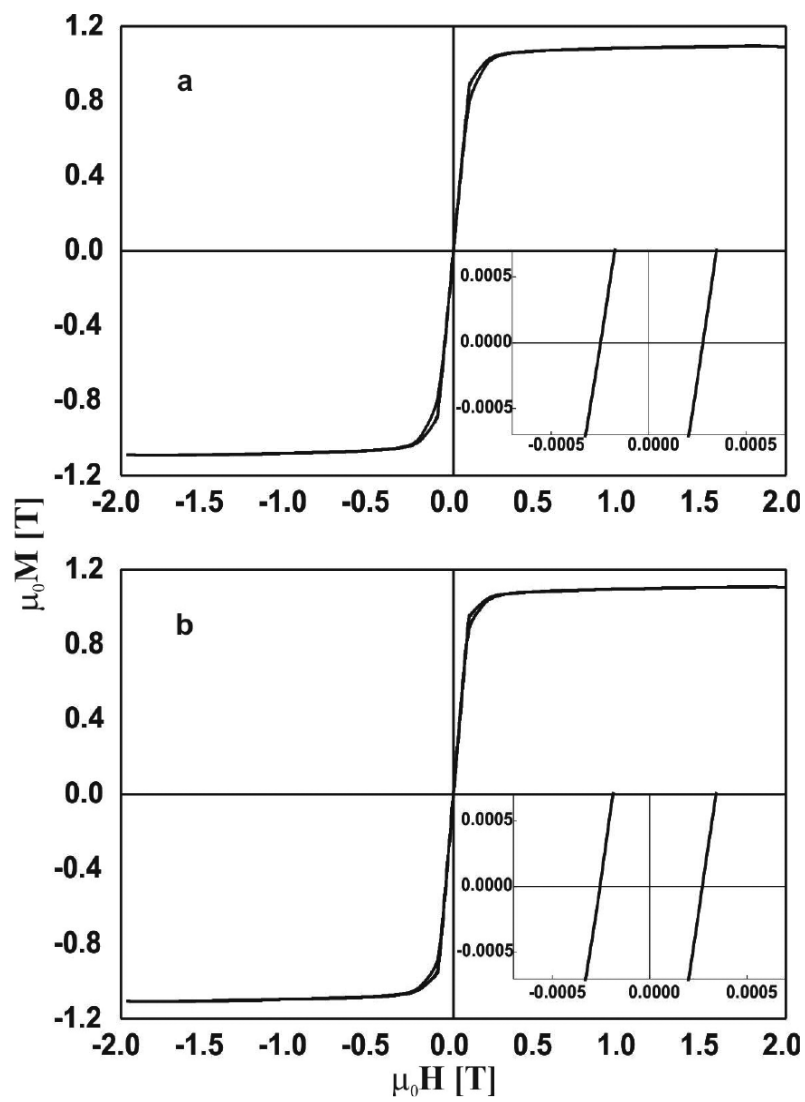

Fig. 5. Static magnetic hysteresis loops measured for the $\mathrm{Fe}_{36} \mathrm{Co}_{36} \mathrm{Y}_{8} \mathrm{~B}_{20}$ alloy produced using: a) injection, b) suction Rys. 5. Statyczne pętle histerezy magnetycznej dla stopu $\mathrm{Fe}_{36} \mathrm{Co}_{36} \mathrm{Y}_{8} \mathrm{~B}_{20}$ wytworzonego metodą: a) wtlaczania, b) zasysania 

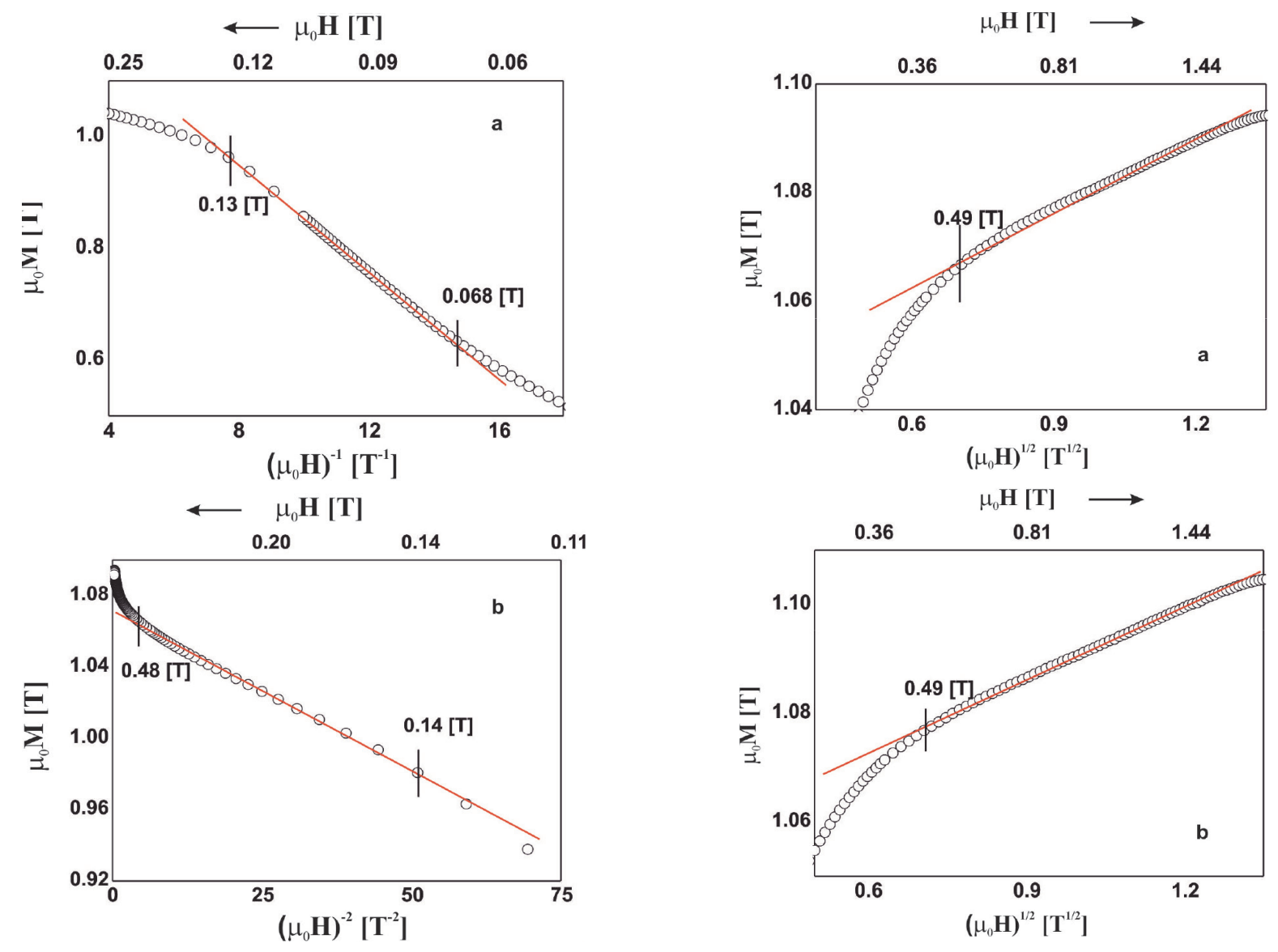

Fig. 6. High-field magnetic polarisation curves for the $\mathrm{Fe}_{36} \mathrm{Co}_{36} \mathbf{Y}_{8} \mathrm{~B}_{20}$ alloy produced using injection method: a) $\left(\mu_{0} \mathbf{H}\right)^{-1}$, b) $\left(\mu_{0} \mathbf{H}\right)^{-2}$

Rys. 6. Magnetyzacja dla stopu $\mathrm{Fe}_{36} \mathrm{Co}_{36} \mathrm{Y}_{8} \mathrm{~B}_{20}$ wytworzonego metodą wtlaczania w funkcji: a) $\left(\mu_{0} \mathrm{H}\right)^{-1}$, b) $\left(\mu_{0} \mathrm{H}\right)^{-2}$

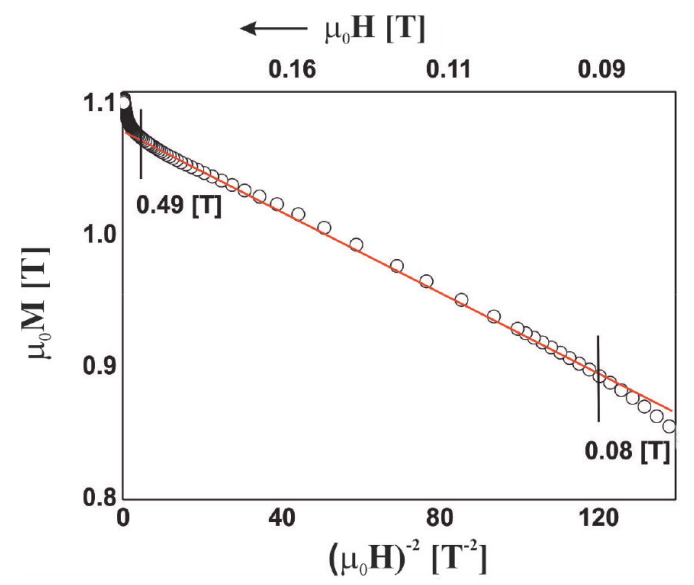

Fig. 7. High-field magnetic polarisation curve as a function of $\left(\mu_{0} H\right)^{-2}$ for the $\mathrm{Fe}_{36} \mathrm{Co}_{36} \mathrm{Y}_{8} \mathrm{~B}_{20}$ alloy produced using suction casting method

Rys. 7. Magnetyzacja $w$ funkcji $\left(\mu_{0} H\right)^{-2}$ dla stopu $\mathrm{Fe}_{36} \mathrm{Co}_{36} \mathbf{Y}_{8} \mathbf{B}_{20}$ wytworzonego metoda zasysania

Determining the linear fit parameter $\mathrm{b}$ and applying expression (5), the spin stiffness parameter $D_{s p f}$ associated with the surrounding magnetic atoms was determined. For a sample of an alloy produced using pressing, this parameter is $51 \mathrm{meVnm} 2$, while for a sample cast using suction it is $51.3 \mathrm{meVnm} 2$. It can therefore be assumed that the value of saturation magnetisation and spin wave stiffness for samples produced using two methods is the same.

Fig. 8. High-field magnetic polarisation curves as a function of $\left(\mu_{0} H\right)^{1 / 2}$ for the $\mathrm{Fe}_{36} \mathrm{Co}_{36} \mathrm{Y}_{8} \mathrm{~B}_{20}$ alloy produced using: a) injection, b) suction

Rys. 8. Magnetyzacja $w$ funkcji $\left(\mu_{0} H\right)^{1 / 2}$ dla stopu $\mathrm{Fe}_{36} \mathrm{Co}_{36} \mathrm{Y}_{8} \mathrm{~B}_{20}$ wytworzonego metodą: a) wtłaczania, b) zasysania

\section{CONCLUSIONS}

The purpose of the study was to create a massive ironbased amorphous alloy with a high content of yttrium and to study its structure and selected magnetic properties. X-ray diffractograms measured for the materials produced were typical for amorphous materials. An indirect study of the structure, which is the measurement of magnetic saturation polarisation curves as a function of temperature, confirms the absence of other magnetic phases in the volume of samples produced than the identified amorphous matrix. The alloy produced with two methods was characterised by high Curie temperature (about $750 \mathrm{~K}$ ). The Curie temperature for crystalline materials is a discrete value, whereas in the case of amorphous materials we observe a temperature range in which the transition from the ferro- to the paramagnetic state occurs. This is related to the inhomogeneity of the amorphous matrix. Its volume includes micro-areas differing in chemical composition. Therefore, we are observing magnetic transition of these areas in similar, but not identical temperatures. Therefore, it is possible to deviate from the Curie temperature values for the same alloy produced using different methods. The conducted research confirms the possibility of producing massive amorphous materials based on FeCoYB characterised by the so-called 'good soft magnetic properties'. The produced alloy samples were characterised 
by a similar saturation magnetisation and coercive field. The produced alloy samples were subjected to a magnetising process in an area called the 'approach to ferromagnetic saturation' in a similar manner. The non-uniformity of the magnetic structure in the form of pseudo-lockable dipoles had an influence on the process of magnetising the produced materials. The $D_{s p f}$ parameter is related to the surrounding of magnetic atoms.
In the case of the tested alloys, these are the pairs of $\mathrm{Fe}-\mathrm{Fe}, \mathrm{Co}-\mathrm{Co}$ and Fe-Co atoms. Similar values of $D_{s p f}$ and saturation magnetisation lead to the conclusion that the method of delivering the liquid alloy to a copper mould does not significantly affect the degree of disorder of the structure, which is also indicated by almost identical X-ray diffraction images.

\section{REFERENCES}

[1] W. Klement, R.H. Willens, P. Duwez. Non-Crystalline Structure in Solidified Gold-Silicon Alloys. Nature, 1960, 187, p. 869-870.

[2] P. Duwez, R.H. Willens. Rapid Quenching of Liquid Alloys. Transactions of the Metallurgical Society of Aime, 1963, 227, p. $362-365$.

[3] A. Inoue, T. Zhang, T. Masumoto. Zr-Al-Ni Amorphous Alloys with High Glass Transition Temperature and Significant Supercooled Liquid Region. Materials Transactions JIM, 1990, 31, p. 177-183.

[4] A. Inoue, A. Kato, T. Zhang, S.G. Kim, T. Masumoto. Mg-Cu-Y Amorphous Alloys with High Mechanical Strengths Produced by a Metallic Mold Casting Method. Materials Transaction JIM, 1991, 32, p. 609-616.

[5] G. Herzer. Modern soft magnets: Amorphous and nanocrystalline materials. Acta Materialia, 2013, 61, p. 718-734.

[6] M.E. McHenry, M.A. Willard, D.E. Laughlin. Amorphous and nanocrystalline materials for applications as soft magnets. Prog. Mater. Sci., 1999, 44, p. 291.

[7] Y. Geng, Y. Wang, Z. Wang, J. Qiang, H. Wang, C. Dong, O. Tegus. Formation and structure-property correlation of new bulk Fe-B-Si-Hf metallic glasses. Materials and Design, 2016, 106, p. 69-73.

[8] G. Herzer. Soft magnetic nanocrystalline materials. Scripta Metallurgica et Materialia, 1995, 33, p. 1741-1756.

[9] A. Inoue. Bulk amorphous alloys with soft and hard magnetic properties. Materials Science and Engineering A, 1997 226-228, p. 357-363.
[10] H. Liebermann. Rapidly Solidified Alloys, New Jersey Springer Handbook, 1993.

[11] Y. Han, C.T. Chang, S.L. Zhu, A. Inoue, D.V. Louzguine-Luzgin, E. Shalaan, F. Al-Marzouki Fe-based soft magnetic amorphous alloys with high saturation magnetization above $1.5 \mathrm{~T}$ and high corrosion resistance, Intermetallics, 2014,54, p. $169-175$.

[12] B. Jeż. Effect of annealing on the Curie Temperatre in the bulk amorphous alloys. Revista de Chimie, 2017, 68 (2), p. 1903-1907.

[13] M. Nabialek. Influence of the quenching rate on the structure and magnetic properties of the Fe-based amorphous alloy. Arch. Metall. Mater., 2016, 61, p. 439-444.

[14] K. Bloch, M. Nabialek. Acta Physica Polonica A, 2015, 127, p. $413-414$.

[15] S. Garus, M. Nabialek, K. Bloch, J. Garus. The Study of Magnetization in Strong Magnetic Fields for Alloys $\mathrm{Fe}_{60} \mathrm{Co}_{10} \mathrm{~W}_{\mathrm{x}}$ $\mathrm{Nb}_{2} \mathrm{Y}_{8} \mathrm{~B}_{20-\mathrm{x}}(\mathrm{x}=0,1)$. Acta Physica Polonica A, 2014, 126, p. 957-959 .

[16] H. Kronmüller, M. Fahnle, H. Grimm, R. Grimm, B. Groger. Magnetic properties of amorphous ferromagnetic alloys. J. Magn. Magn. Mater., 1979, 13, p. 53-70.

[17] H. Kronmüller. Micromagnetism and Microstructure of Amorphous Alloys. J. Appl. Phys., 1981, 52, p. 1859-1864. 